\title{
EVERGREEN UNDERSTORY DYNAMICS IN COWEETA FOREST, NORTH CAROLINA
}

\author{
M. M. Dobbs \\ Natural Resources Spatial Analysis Laboratory \\ Institute of Ecology \\ University of Georgia \\ Athens, Georgia 30602
}

\author{
Albert J. Parker \\ Department of Geography \\ University of Georgia \\ Athens, Georgia 30602
}

\begin{abstract}
A number of studies have elucidated the distributional patterns of various components of Southern Appalachian forests. The evergreen understory here is composed largely of a dominant ericaceous shrub, Rhododendron maximum L., which is believed to be expanding and inhibiting the development of other species with consequent impacts on overall forest structure and composition. We use a GIS and logistic regression to examine this less-studied forest element in the Coweeta Hydrological Laboratory, North Carolina, over a 17-year period to determine whether expansion is occurring and, if so, whether it can be predicted based on terrain characteristics. We examine two adjacent, physically similar basins with differing degrees of experimental manipulation in the 20th century in an attempt to examine the role of environmental and historical factors in determining spatial patterns of persistence, expansion, and decline of the evergreen understory. Results indicate that significant expansion of the evergreen understory occurred in both basins during the period 1976-1993, and that stream proximity, topographic setting, and elevation are related to patterns of evergreen-understory dynamics. Patterns differ between the two basins, suggesting that disturbance and differing land-use histories are also influential. Predictive power of models based on terrain factors alone ranges from $<10 \%$ to $>50 \%$. [Key words: vegetation dynamics, Appalachians, GIS, understory, Rhododendron maximum.]
\end{abstract}

\section{INTRODUCTION}

The forests of the Southern Appalachian Mountains are among the most diverse temperate upland forests in the world (Whittaker, 1956). A prominent feature of these forests is an extensive ericaceous evergreen understory, in many places dominated by Rhododendron maximum (rosebay) or Kalmia latifolia (mountain laurel). This evergreen-understory layer plays an important role in modulating overstory vegetation dynamics, as it shades the forest floor and favors regeneration by shade tolerant tree species, at the expense of less tolerant taxa. In the past few decades, observational evidence has accumulated to suggest that the ericaceous evergreen understory, and especially Rhododendron maximum, has expanded its areal 
coverage in mesic and dry-mesic forests of the Southern Appalachians. Our primary purposes in this paper are: (1) to document this presumed expansion by employing geographic information systems (GIS) to investigate forest understory changes evident in large-scale aerial photographs between two time periods (1976 and 1993), (2) to explore associations between patterns of understory-vegetation change and environmental gradients with logistic regression, and (3) to interpret patterns of change in light of both environmental limits and disturbance history.

Earlier work (Dobbs, 1998) has identified several topographic elements that influence local moisture supply and are related to the distribution of Rhododendron maximum: slope aspect, stream proximity, and elevation. In this paper, we examine possible relationships between evergreen-understory expansion in the Coweeta Hydrologic Laboratory and these topographic constraints. We have attempted to take advantage of a natural experiment in research design by comparing evergreenunderstory spatial patterns between the two drainage basins encompassed by the Coweeta Hydrologic Laboratory. The larger and more northerly of the two basins, Coweeta (1626 ha), is the site of numerous watershed-based and smaller scale studies. Dryman Fork Basin (559 ha) borders Coweeta Basin to the south, and has been unmanipulated since the late 1920s. Both watersheds drain eastward and have similar topographic forms in terms of elevation, aspect, and stream density.

\section{SITE DESCRIPTION}

Coweeta Hydrologic Laboratory (henceforth, Coweeta Lab) has been a center for forest hydrology research since 1934, under the auspices of the U.S. Forest Service, and is now operated as a Long Term Ecological Research facility in cooperation with the University of Georgia and other academic institutions. Coweeta Lab is located in the Blue Ridge physiographic province of the southern Appalachian Mountains, Macon County, North Carolina $\left(35^{\circ} 03^{\prime} \mathrm{N}, 83^{\circ} 25^{\prime} \mathrm{W}\right)$. Topography at the $\mathrm{Lab}$ is varied, with slope steepness varying from $0^{\circ}$ to $89^{\circ}$, slope aspect encompassing a full $360^{\circ}$ range, and elevation ranging from $675 \mathrm{~m}$ in the eastern portion of the basin to $1592 \mathrm{~m}$ atop Mt. Albert. Precipitation increases generally with elevation from east to west, averaging $1821 \mathrm{~mm} / \mathrm{yr}$. (Swift, 1988). The climate is temperate, with a mean annual temperature of $13^{\circ} \mathrm{C}$. Forest overstory is mixed, ranging from cove hardwoods in low, moist sites to oak-pine associations on dry ridges; understory is typically dominated by ericaceous shrubs.

Human impact prior to 1837 consisted of periodic selective burning of woodlands by the resident Native Americans for at least 4000 years for, among other purposes, the attraction of game animals to the grassy openings (Hammett, 1992; Delcourt and Delcourt, 1997). European settlers arrived in 1842 and began to cultivate small areas of bottomland; in addition, they cleared land for grazing livestock and continued the practice of regular burning into the early 20th century, at which time the land was heavily logged. The U.S. Forest Service began managing the basin area in 1923 with a policy of fire suppression and cessation of logging and grazing except for small-scale experimental manipulations. At about the same time, chestnut blight (Endothia parasitica [Murr.] P.) was spreading through the region and by 1940 had virtually extirpated American chestnut (Castanea dentata) at Coweeta 
Lab. Douglass and Hoover (1988) estimated that American chestnut occupied about $40 \%$ of the overstory in the early 1900 s. This figure is supported by a vegetation survey of one 29-ha watershed at Coweeta which disclosed a reduction of chestnut basal area from about $41 \%$ in 1934 to less than $1 \%$ in 1953 (Nelson, 1955). Climatically, the Coweeta Lab has endured several droughts during the past century, the most pronounced of which was in the 1920 s.

\section{METHODS}

For the Coweeta and Dryman Fork Basins, we made areal comparisons at the basin level, looking for differences that might implicate differing early land-use histories in determining the evergreen-understory pattern at Coweeta. These measurements were based on digital maps derived from leaf-off aerial photographs flown in 1976 at a scale of 1:24,000 (true color) and, in 1993, at a scale of 1:6000 (infrared; Dobbs, 1998). All photo interpretation was stereoscopically performed to minimize planimetric distortions imposed by the rugged terrain. We assigned land areas to one of five understory-vegetation types: predominantly Rhodendron maximum ( $>70 \%$ cover, (RHO), predominantly Kalmia latifolia ( $>70 \%$ cover) (KAL), mixed Rhododendron-Kalmia (MIX), predominantly Rhododendron catawbiense (CAT), and virtually no evergreen-understory cover (NON). Ground-truthing at a network of 63 sites in Coweeta Lab revealed 78\% accuracy in determination of understory-vegetation types from the 1993 photos. Of the 10 errors, six were misclassifications of MIX as RHO. We overlaid the two maps in a raster-based GIS platform (IDRISI), then cross-tabulated to produce understory-evergreen change images for the 17-year period between photos.

A large body of research utilizes geographic information systems (GIS) as a tool for the study of landscape-level vegetation dynamics and for predictive modeling of vegetation in a variety of ecosystems (Jensen et al., 1992; Brzeziecki et al., 1993; Baker et al., 1995; del Barrio et al., 1997). Bivariate logistic regression has been commonly used to investigate spatial relationships in a GIS environment, particularly given the nonlinear nature of most ecological relationships and the fact that dependent variables are often categorical (de Swart et al., 1994; Akashi and Mueller-Dombois, 1995; Bian and West, 1997; Narumalani et al., 1997). In this study, the response variable (change in understory-vegetation type) is categorical, can take on a range of values or settings, and has no natural ordering. We employed a multinomial logit in which the link function is the log of the odds, and the random component assumes a multinomial distribution, to relate patterns of change to possible environmental controls (Liao, 1994; Agresti, 1996).

In developing explanatory models based on environmental gradients, we removed from consideration treatment (experimental) watersheds in the Coweeta Lab in order to eliminate the possible confounding effects of recent silvicultural manipulation. A stratified random sample of points was drawn from the remaining portion of Coweeta Basin (henceforth Coweeta-Unmanaged) and the adjoining Dryman Fork Basin, resulting in a sample size of 536 pixels, with each pixel of 10$\mathrm{m}$ dimension (Table 1 ). 
Table 1. Areal Coverage of Evergreen-Understory Change Classes in the Study Area and Representation of Change Classes in the Random Sample Used for Logistic-Regression Modeling

\begin{tabular}{lcccc}
\hline \multicolumn{1}{c}{ Change class } & Areal extent (ha) & $\begin{array}{c}\text { Percent of } \\
\text { study area }\end{array}$ & $\begin{array}{c}\text { Count in } \\
\text { random sample }\end{array}$ & $\begin{array}{c}\text { Percent of } \\
\text { random sample }\end{array}$ \\
\hline NON:NON & 600.99 & 35.93 & 194 & 36.47 \\
RHO:RHO & 401.21 & 23.99 & 120 & 22.56 \\
MIX:MIX & 240.40 & 14.37 & 71 & 13.35 \\
NON:RHO & 147.72 & 8.83 & 53 & 9.96 \\
NON:MIX & 82.79 & 4.95 & 30 & 5.64 \\
RHO:NON & 66.46 & 3.97 & 18 & 3.38 \\
MIX:RHO & 52.83 & 3.16 & 19 & 3.57 \\
MIX:NON & 36.14 & 2.16 & 9 & 1.69 \\
RHO:MIX & 24.58 & 1.47 & 12 & 2.26 \\
\hline
\end{tabular}

${ }^{\mathrm{a}} \mathrm{NON}=$ virtually no evergreen-understory cover; $\mathrm{RHO}=$ predominantly Rhododendron maximum; MIX = mixed Rhododendron-Kalmia.

Potential explanatory variables included in the overall model of understoryevergreen change patterns were elevation (ELEV), a scalar transformation of topographic setting based on Parker's (1982) Topographic Relative Moisture Index (TOPO), distance from stream (DIST), and basin (BASN, a dichotomous dummy variable). TOPO was derived from digital elevation models of the study area. Using the continuous form of four variables, we calculated indices with a value range of $0-2$ ( 0 for the most xeric and 2 for most mesic topographic situation). The four scalar index variables were: slope (SLPIN), aspect (ASPIN), topographic position (TOPIN), and topographic configuration (CFGIN). Following the weightings of Parker (1982), these were combined as follows: TOPO $=(2 *$ TOPIN $)+(2 *$ ASPIN $)+$ $($ SLPIN) + (CFGIN) (Dobbs, 1998). In addition to the overall model, we developed logistic-regression models separately for Coweeta-Unmanaged and Dryman Fork Basins, using ELEV, TOPO, and DIST.

There were 25 theoretically possible evergreen-understory change classes ( 5 for $1976 \times 5$ for 1993; Tables 2 and 3). In tables and in the remainder of the text, we have used the following convention when referring to change classes: vegetation symbols separated by a colon represent transitions between understory classes on the 1976 map and the 1993 map (e.g., NON:RHO mapping units have converted from lacking an evergreen understory in 1976 to $R$. maximum cover in 1993). Some of the 25 potential classes do not occur on the ground: for Coweeta-Unmanaged, there were 18 extant classes represented, for Dryman Fork, 19. Five of these change classes were rare (ranging in area from 0.2 to $5.5 \mathrm{ha}$ ) and not represented in the random sample of modeling points. Four other change categories limited to specific, localized habitats (those involving KAL and CAT) were eliminated from further analysis. Two classes of limited extent and similar ecological significance were combined: MIX:NON and RHO:NON. Of the eight understory-change classes used in further analysis, three classes reflect stability between periods (NON:NON, 
MIX:MIX, RHO:RHO), two reflect shifts in understory composition (RHO:MIX, MIX:RHO), two reflect evergreen-understory expansion (NON:MIX, NON:RHO), and one reflects evergreen-understory contraction (MIX/RHO:NON).

We used a nested modeling approach to examine main effects and interactions among the four candidate explanatory variables (ELEV, TOPO, DIST, BASN) in developing a parsimonious logistic-regression model. Model selection was guided by testing for significant differences in goodness of fit between complex and progressively simpler models, based on $\chi^{2}$ probability. To assess goodness of fit, the $-2 \mathrm{LL}$ maximum likelihood statistic was used to examine the contribution of main variables and interaction terms to the model (Hamilton, 1992).

We calculated outcome probabilities using selected predictor values in order to assess trends and to provide a basis for comparison with actual observations. Variables not being interpreted were kept at their sample means (Liao, 1994). Probabilities were estimated using the logistic model for multiple response categories (Wrigley, 1985):

$$
P_{r \mid i}=\frac{e^{\alpha_{r}+B_{r} X_{i}}}{\sum_{s=1}^{R} e^{\alpha_{s}+B_{s} x_{i}}} \quad r=1,2, \ldots R
$$

where $\left.P_{r}\right|_{i}$ is the probability that the ith individual or locality will select the $r$ th response category.

In order to assess the predictive powers of the various models, we employed a pseudo $R^{2}$ goodness of fit measure (Wrigley, 1985) known as p2. This statistic utilizes a ratio of maximized log likelihood values of fitted and constant-only model:

$$
\rho^{2}=1-\frac{\log _{\mathrm{e}} \Lambda(\hat{B})}{\log _{\mathrm{e}} \Lambda(C)}
$$

where $\Lambda(\hat{B})=$ maximized log likelihood value of the fitted model and $\Lambda(C)=$ maximized log likelihood value of the intercept-only model. This value will lie between 0 and 1 , the closer to 1 the better the fit. Values of $\mathrm{p} 2$ tend to be smaller than $R^{2}$ values achieved by ordinary least squares regression and should be interpreted accordingly (Wrigley, 1985).

\section{RESULTS AND INTERPRETATION}

General Characterization of Evergreen-Understory Change at Coweeta Lab, 1976-1993

Dryman Fork Basin was characterized by a higher percentage of terrain that lacks an evergreen understory, when compared to Coweeta-Unmanaged in either time period ( 37 vs. $56 \%$ in $1976 ; 46$ vs. $64 \%$ in 1993; Table 2). The two major vegetated understory categories, $\mathrm{RHO}$ and MIX, were each areally more extensive in Coweeta-Unmanaged than in Dryman Fork Basin. RHO grew dramatically between 1976 and 1993 in Dryman Fork (+38\%), whereas MIX in Dryman Fork displayed 
Table 2. Areal Extent and Patterns of Change for the Five Evergreen-Understory Categories in 1976 and 1993 for Coweeta-Unmanaged and Dryman Fork Basins ${ }^{\mathrm{a}}$

\begin{tabular}{|c|c|c|c|c|c|c|}
\hline \multirow[b]{2}{*}{ Vegetation class ${ }^{\mathrm{a}}$} & \multicolumn{2}{|c|}{1976} & \multicolumn{2}{|c|}{1993} & \multicolumn{2}{|c|}{ Change } \\
\hline & $\begin{array}{c}\text { Areal } \\
\text { extent (ha) }\end{array}$ & $\begin{array}{c}\text { Percent } \\
\text { area }\end{array}$ & $\begin{array}{c}\text { Area! } \\
\text { extent (ha) }\end{array}$ & $\begin{array}{c}\text { Percent } \\
\text { area }\end{array}$ & $\begin{array}{c}\text { Areal } \\
\text { extent (ha) }\end{array}$ & $\begin{array}{l}\text { Percent } \\
\text { change }\end{array}$ \\
\hline \multicolumn{7}{|c|}{ Coweeta-Unmanaged } \\
\hline $\mathrm{RHO}$ & 360.85 & 32.45 & 417.93 & 37.85 & +57.08 & +15.82 \\
\hline MIX & 261.76 & 23.54 & 289.10 & 26.00 & +27.34 & +10.44 \\
\hline KAL & 0.38 & 0.03 & 2.70 & 0.24 & +2.32 & +610.53 \\
\hline CAT & 0.57 & 0.05 & 1.04 & 0.09 & +0.47 & +82.46 \\
\hline TOTAL VEG & 623.56 & 56.06 & 710.77 & 63.90 & +87.21 & +13.99 \\
\hline NON & 488.73 & 43.94 & 401.57 & 36.10 & -87.16 & -17.83 \\
\hline \multicolumn{7}{|l|}{ Dryman Fork } \\
\hline $\mathrm{RHO}$ & 133.68 & 23.81 & 184.34 & 32.84 & +50.66 & +37.90 \\
\hline $\mathrm{MIX}$ & 71.01 & 12.65 & 59.76 & 10.65 & -11.25 & -15.84 \\
\hline $\mathrm{KAL}$ & 0.81 & 0.14 & 2.72 & 0.48 & +1.91 & +235.80 \\
\hline CAT & 4.64 & 0.83 & 9.07 & 1.62 & +4.43 & +95.47 \\
\hline TOTAL VEG & 210.14 & 37.43 & 255.89 & 45.58 & +45.75 & +21.77 \\
\hline NON & 351.24 & 62.57 & 305.49 & 54.42 & -45.75 & -13.03 \\
\hline
\end{tabular}

${ }^{\mathrm{a}} \mathrm{RHO}=$ predominantly Rhododendron maximum; $\mathrm{MIX}=$ mixed Rhododendron-Kalmia; $\mathrm{KAL}=$ Kalmia latifolia; CAT = predominantly Rhododendron catawbiense; TOTAL VEG = summary of the four vegetated evergreen understory categories; $\mathrm{NON}=$ virtually no evergreen-understory cover.

contraction during this same period $(-16 \%)$. By contrast, both RHO and MIX expanded at comparable rates $(+10$ to $+16 \%)$ in Coweeta-Unmanaged.

Despite interbasin contrasts in the extent of vegetated evergreen understory, the two basins exhibited strikingly similar aggregate rates of evergreen-understory expansion (Table 2). There was a net expansion of 46 ha, or $8 \%$ of total basin area, from unvegetated to vegetated evergreen-understory conditions in Dryman Fork between 1976 and 1993. Similarly, Coweeta-Unmanaged experienced a net expansion of 87 ha, again $8 \%$ of total area.

Details of this generalized understory expansion suggest that it is not a simple conversion from one cover type to another, but a complex pattern of changes yielding an aggregate net increase in evergreen-understory cover. For example, in Coweeta-Unmanaged, approximately 840 ha were unchanged between 1976 and 1993; 71 ha lost evergreen-understory cover while 158 ha experienced evergreenunderstory expansion; and 44 ha underwent class changes between vegetated categories. In Dryman Fork, 406 ha underwent no change; 34 ha lost evergreen understory while 80 ha experienced evergreen-understory expansion, and vegetated class changes occurred on 40 ha.

Rhododendron maximum is widespread and persistent over the study period in both Coweeta and Dryman Fork basins (Fig. 1), particularly in valley bottoms and on north-facing slopes. Rhododendron maximum expansion is notable along water- 

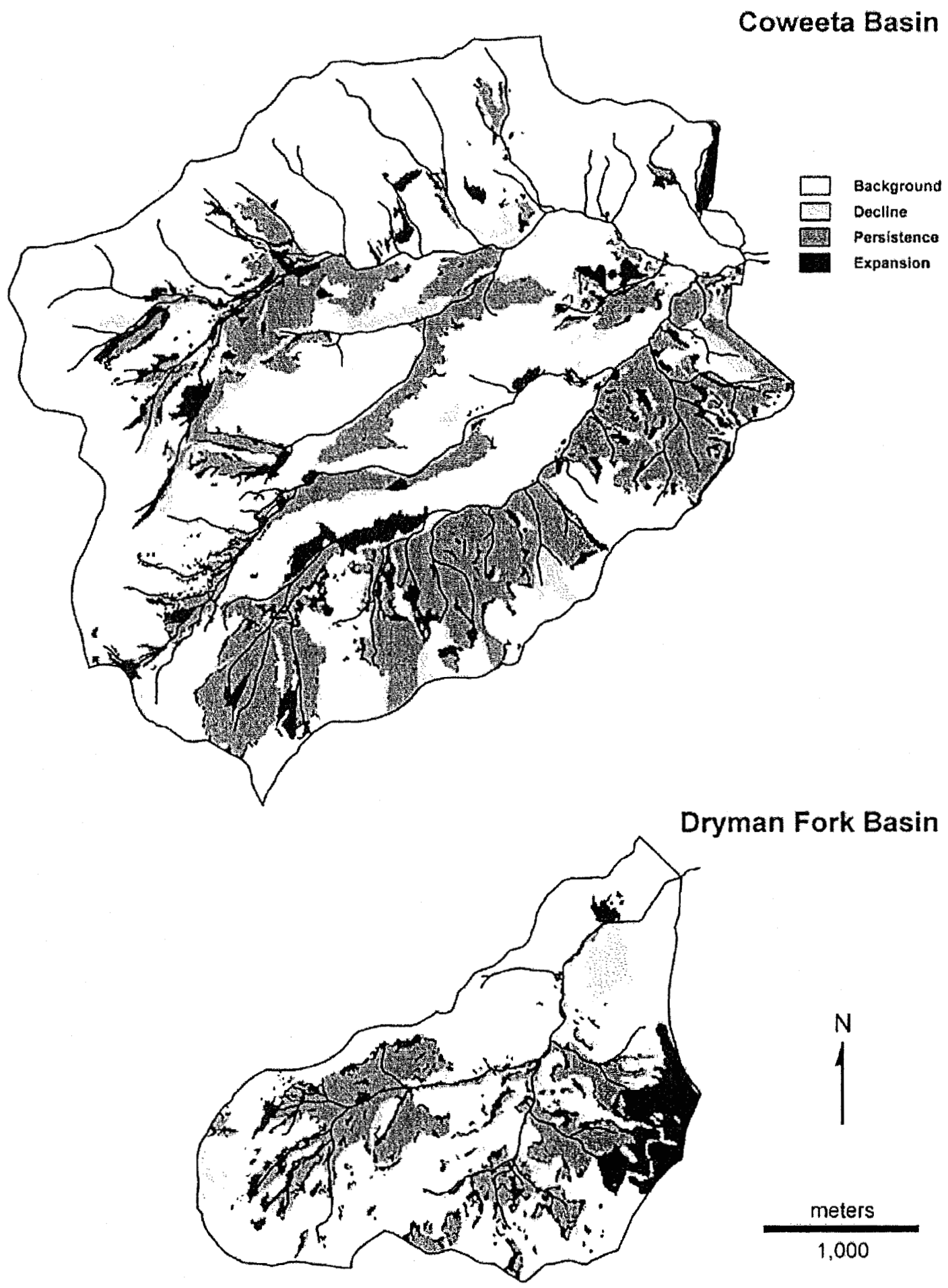

Fig. 1. Spatial patterns of change in Rhododendron maximum cover in Coweeta and Dryman Fork Basins, North Carolina, 1976-1993.

courses as well as around the peripheries of existing Rhododendron maximum patches. Mixed Rhodendron maximum/Kalmia latifolia cover is common on 

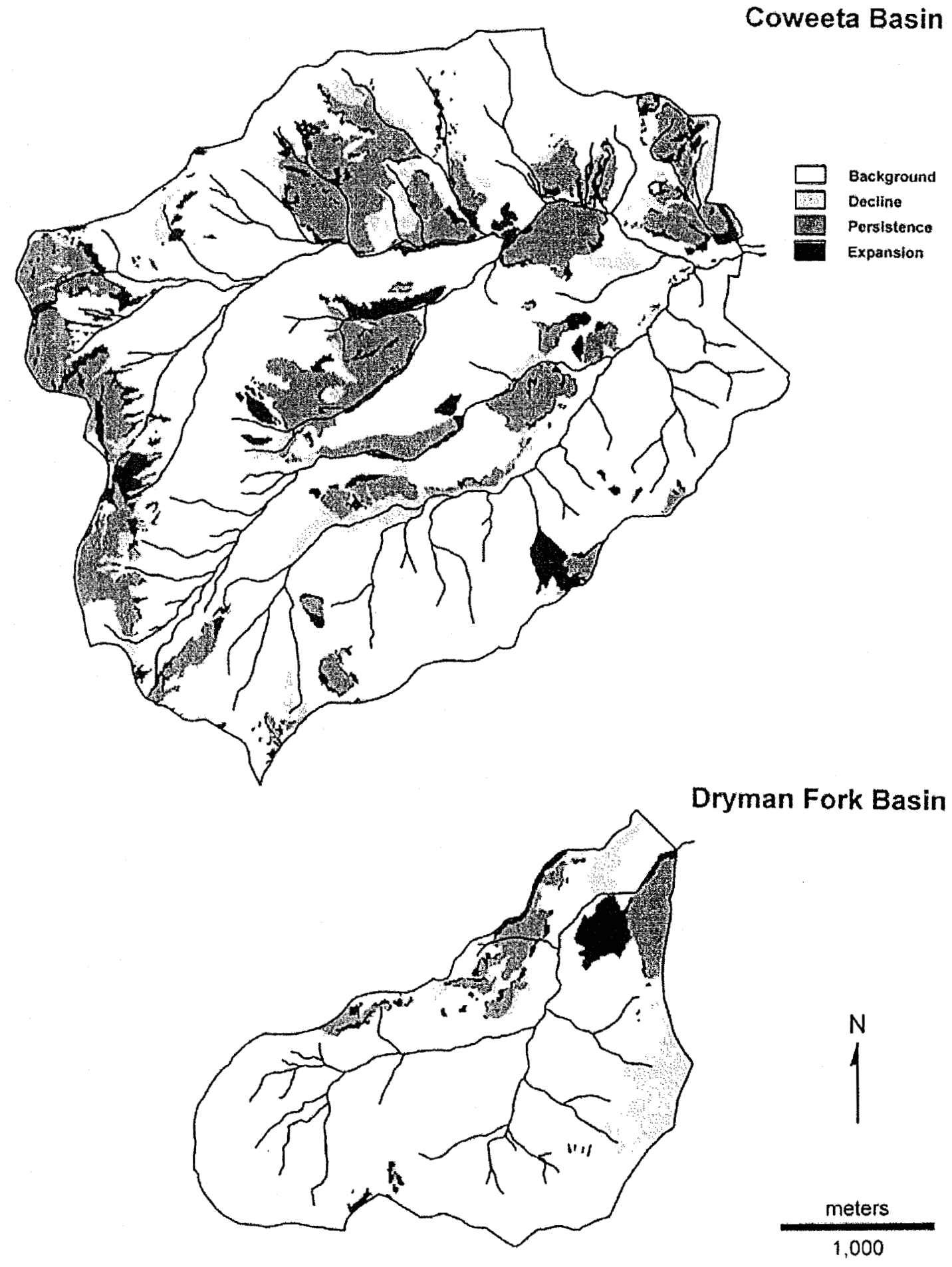

Fig. 2. Spatial patterns of change in mixed evergreen understory cover in Coweeta and Dryman Fork Basins, North Carolina, 1976-1993.

south-facing slopes and along the middle-high elevation flanks of the western margin of Coweeta Basin; it is more limited in distribution in Dryman Fork (Fig. 2). Expansion 


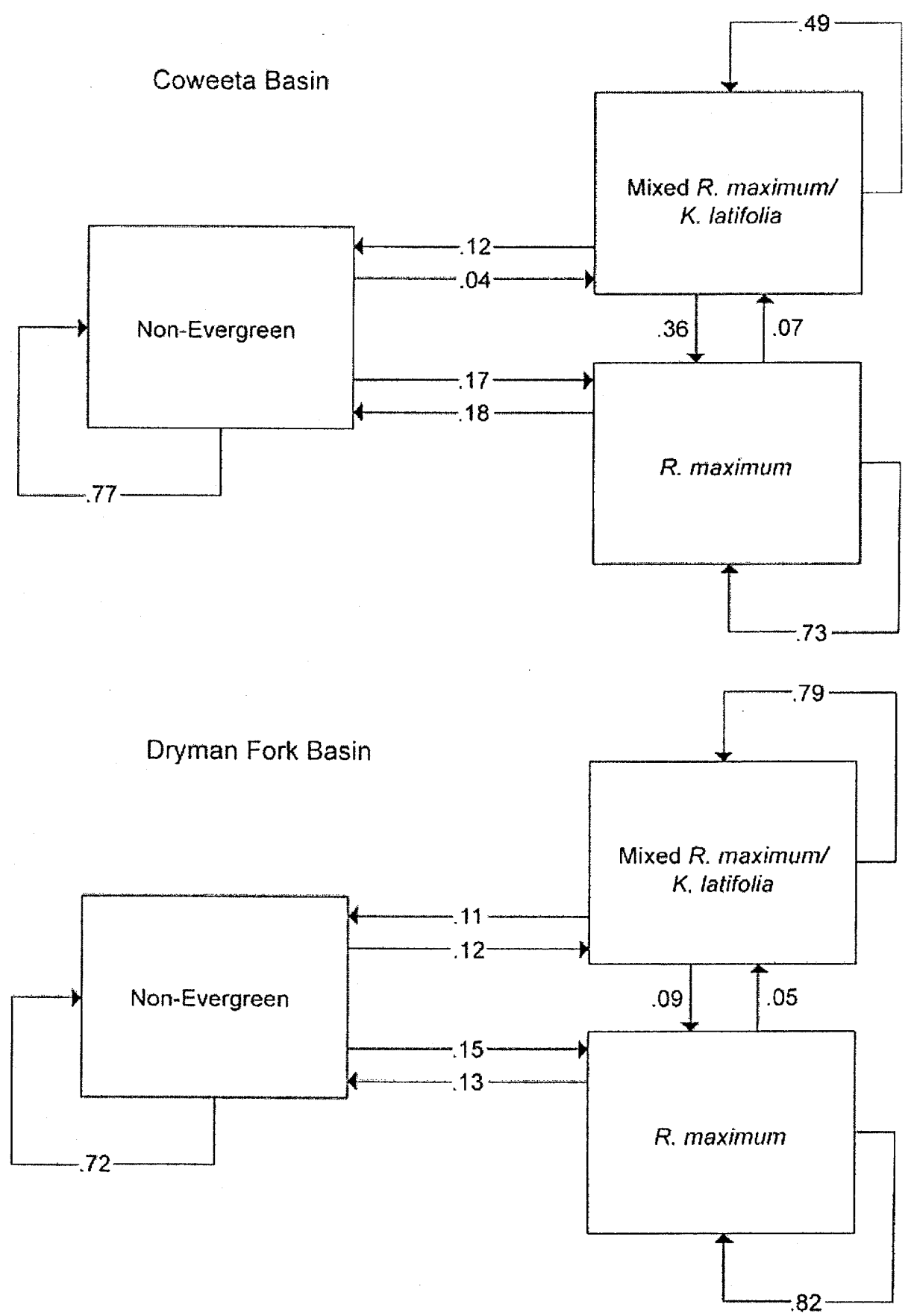

Fig. 3. Transition probabilities for major classes of evergreen understory change in Coweeta and Dryman Fork Basins, North Carolina, 1976-1993.

of this mixed evergreen understory is generally along the edges of existing patches.

Transition probabilities, based on understory vegetation-class changes between time periods, show that all major categories were more likely to persist than to convert to another class over the 17-year study period (Fig. 3), regardless of basin. 
Table 3. Multinomial Logit Model Results ${ }^{a}$

\begin{tabular}{|c|c|c|c|c|c|c|c|}
\hline \multirow[b]{3}{*}{ Predictor } & \multicolumn{7}{|c|}{ Response events $^{\mathrm{b}}$} \\
\hline & \multicolumn{2}{|c|}{ Persistence } & \multicolumn{2}{|c|}{ Class conversion } & \multicolumn{2}{|c|}{ Expansion } & \multirow{2}{*}{$\begin{array}{c}\text { Decline } \\
\text { MIX/RHO: } \\
\text { NON }\end{array}$} \\
\hline & $\begin{array}{l}\text { RHO: } \\
\text { RHO }\end{array}$ & $\begin{array}{l}\text { MIX: } \\
\text { MIX }\end{array}$ & $\begin{array}{l}\text { MIX: } \\
\text { RHO }\end{array}$ & $\begin{array}{l}\text { RHO: } \\
\text { MIX }\end{array}$ & $\begin{array}{l}\text { NON: } \\
\text { MIX }\end{array}$ & $\begin{array}{l}\text { NON: } \\
\text { RHO }\end{array}$ & \\
\hline \multicolumn{8}{|c|}{ Coweeta-Unmanaged } \\
\hline \multirow[t]{2}{*}{ TOPO Index } & $1.270^{* * *}$ & -0.431 & 0.176 & -0.913 & -0.244 & $1.391^{* * *}$ & -0.220 \\
\hline & $(0.269)$ & $(0.242)$ & $(0.507)$ & $(0.625)$ & $(0.336)$ & $(0.412)$ & $(0.368)$ \\
\hline \multirow{2}{*}{$\begin{array}{l}\text { Distance to } \\
\text { stream }\end{array}$} & $-0.010^{* * *}$ & -0.000 & $-0.015^{*}$ & -0.002 & -0.002 & $-0.009^{* *}$ & -0.002 \\
\hline & $(0.002)$ & $(0.007)$ & $(0.006)$ & $(0.003)$ & $(0.004)$ & $(0.004)$ & 0.004 \\
\hline \multicolumn{8}{|l|}{ Dryman Fork } \\
\hline \multirow[t]{2}{*}{ Elevation } & 0.001 & $-0.015^{* *}$ & 0.002 & $-0.027^{* *}$ & -0.007 & 0.001 & -0.004 \\
\hline & $(0.001)$ & $(0.005)$ & $(0.003)$ & $(0.009)$ & $(0.004)$ & $(0.002)$ & $(0.004)$ \\
\hline \multirow{2}{*}{$\begin{array}{l}\text { Distance to } \\
\text { stream }\end{array}$} & $-0.011^{* *}$ & 0.018 & 0.004 & $0.021^{*}$ & 0.005 & -0.003 & $0.010^{*}$ \\
\hline & $(0.003)$ & $(0.006)$ & $(0.004)$ & $(0.009)$ & $(0.006)$ & $(0.003)$ & $(0.005)$ \\
\hline
\end{tabular}

${ }^{\mathrm{a}}$ Maximum likelihood parameter estimates (with standard errors beneath) are listed for CoweetaUnmanaged and Dryman Fork Basin. NON:NON serves as the reference standard for all response events.

${ }^{\mathrm{b}} \mathrm{RHO}=$ predominantly Rhododendron maximum; $\mathrm{MIX}=$ mixed Rhododendron-Kalmia; NON = virtually no evergreen-understory cover.

${ }^{*} p<.05 .{ }^{* *} p<.01 .{ }^{* * *} p<.001$.

Terrain lacking an evergreen understory and Rhododendron maximum were especially tenacious, with persistence levels of $72-82 \%$ in both basins. Mixed Rhododendron maximum/Kalmia latifoia was much less persistent in Dryman Fork than Coweeta-Unmanaged. Indeed, a significant percentage of the Rhododendron maximum increase in Dryman Fork was attributable to class conversion from MIX, rather than direct expansion onto unvegetated terrain.

Logistic-Regression Models of Evergreen-Understory Change at Coweeta Lab, 1976-1993

For the entire study area, the final model identified by our likelihood ratio test retained five variables-ELEV, TOPO, DIST, plus multiplicative interaction terms incorporating basin identification (BASN) with ELEV and TOPO. These basin-linked interaction terms suggest that evergreen-understory dynamics respond differently to both elevation and topographic setting between the two basins. Because the overall model was unnecessarily complicated in structure, we developed separate, more parsimonious models for each basin, the Coweeta-Unmanaged logistic model retaining two variables (TOPO, DIST) and the Dryman Fork model retaining two variables (ELEV, DIST). Both TOPO and DIST exhibit significant maximum likelihood parameter estimates for Rhododendron maximum persistence and expansion in Coweeta-Unmanaged (Table 3). In Dryman Fork, elevation is significantly related 
Table 4. Predicted Probabilities of Occurrence of Understory-Vegetation Change Classes in Coweeta Basin-Unmanaged ${ }^{\text {ab }}$

\begin{tabular}{|c|c|c|c|c|c|c|c|c|}
\hline \multirow[b]{3}{*}{$\begin{array}{c}\text { TOPO Index } \\
\text { (xeric to mesic) }\end{array}$} & \multicolumn{8}{|c|}{ Gradient of aspect index values } \\
\hline & \multicolumn{2}{|c|}{ Persistence } & \multicolumn{3}{|c|}{ Class conversion } & \multicolumn{2}{|c|}{ Expansion } & \multirow{2}{*}{$\begin{array}{c}\text { Decline } \\
\text { MIX-RHO: } \\
\text { NON }\end{array}$} \\
\hline & $\begin{array}{l}\text { NON: } \\
\text { NON }\end{array}$ & $\begin{array}{l}\text { RHO: } \\
\text { RHO }\end{array}$ & $\begin{array}{l}\text { MIX: } \\
\text { MIX }\end{array}$ & $\begin{array}{l}\text { MIX: } \\
\text { RHO }\end{array}$ & $\begin{array}{l}\text { RHO: } \\
\text { MIX }\end{array}$ & $\begin{array}{l}\text { NON: } \\
\text { MIX }\end{array}$ & $\begin{array}{l}\text { NON: } \\
\text { RHO }\end{array}$ & \\
\hline 0.0 & .351 & .045 & .328 & .018 & .054 & 107 & .013 & .084 \\
\hline 0.5 & .359 & .088 & .297 & .020 & .035 & .098 & .027 & .077 \\
\hline 1.0 & .345 & .159 & .252 & .021 & .021 & .084 & .051 & .066 \\
\hline 1.5 & .302 & .262 & .195 & .020 & .012 & .066 & .090 & .052 \\
\hline \multirow[t]{2}{*}{2.0} & .234 & .385 & .134 & .017 & .006 & .045 & .141 & .036 \\
\hline & \multicolumn{8}{|c|}{ Gradient of stream proximity values } \\
\hline \multicolumn{9}{|c|}{ Distance from stream } \\
\hline 0 & .203 & .358 & 147 & .061 & .013 & .059 & .112 & .046 \\
\hline 100 & .323 & .211 & .223 & .023 & .016 & .076 & .070 & .059 \\
\hline 200 & 419 & .101 & .278 & .006 & .017 & .079 & .036 & .063 \\
\hline 300 & .482 & .043 & .308 & .002 & .015 & .074 & .016 & .059 \\
\hline 400 & .523 & .017 & .322 & .000 & .013 & .064 & .007 & .053 \\
\hline
\end{tabular}

${ }^{2}$ Other environmental variables held at their mean values.

${ }^{\mathrm{b}} \mathrm{NON}=$ virtually no evergreen-understory cover; $\mathrm{RHO}=$ predominantly Rhododendron maximum; MIX = mixed Rhododendron-Kalmia.

to mixed Rhododendron maximum/Kalmia latifolia persistence, whereas DIST, as in Coweeta-Unmanaged, is related to Rhododendron maximum persistence between periods of study. Neither ELEV nor DIST were significant predictors of evergreenunderstory expansion in Dryman Fork.

Domencich and McFadden (1975, in Wrigley, 1985) suggested that a very good model fit is indicated by $p^{2}$ values between 0.2 and 0.4 . Both model $p^{2}$ values lie somewhat below this standard. The overall fit of the Dryman Fork model $\left(p^{2}=\right.$ $0.156)$ is better than that of the Coweeta-Unmanaged model $\left(p^{2}=0.111\right)$. Overall prediction success for evergreen-understory change categories, based on the sample points, is $25 \%$ for Coweeta-Unmanaged and 35\% for Dryman Fork. Although these values are quantitatively modest, they represent a significant improvement over the $12.5 \%$ success rate that would be achieved by random assignment of pixels to one of eight categories. For Coweeta-Unmanaged, the greatest prediction success (33-35\%) is achieved for the persistence categories- $\mathrm{RHO}$ : RHO and NON:NON. Prediction success in Dryman Fork is elevated primarily by its increased ability to predict NON:NON (52\%), which is attributable to the greater extent of terrain lacking an evergreen understory in this basin. In general, models for each basin are best at predicting persistence between time periods. Class conversions, expansion, and decline are less well modeled. 
Table 5. Predicted Probabilities of Occurrence of Understory-Vegetation Change Classes in Dryman Fork Basin ${ }^{\text {ab }}$

\begin{tabular}{|c|c|c|c|c|c|c|c|c|}
\hline \multirow[b]{3}{*}{ Elevation $(\mathrm{m})$} & \multicolumn{8}{|c|}{ Gradient of elevation values } \\
\hline & \multicolumn{2}{|c|}{ Persistence } & \multicolumn{3}{|c|}{ Class conversion } & \multicolumn{2}{|c|}{ Expansion } & \multirow{2}{*}{$\begin{array}{l}\text { Decline } \\
\text { MIX-RHO: } \\
\text { NON }\end{array}$} \\
\hline & $\begin{array}{l}\text { NON: } \\
\text { NON }\end{array}$ & $\begin{array}{l}\text { RHO: } \\
\text { RHO }\end{array}$ & $\begin{array}{l}\text { MIX: } \\
\text { MIX }\end{array}$ & $\begin{array}{l}\text { MIX: } \\
\text { RHO }\end{array}$ & $\begin{array}{l}\text { RHO: } \\
\text { MIX }\end{array}$ & $\begin{array}{l}\text { NON: } \\
\text { MIX }\end{array}$ & $\begin{array}{l}\text { NON: } \\
\text { RHO }\end{array}$ & \\
\hline 0.0 & 700 & .047 & .012 & .126 & .001 & .774 & .020 & .011 \\
\hline 0.5 & 900 & .506 & .145 & .067 & .025 & .037 & .056 & .124 \\
\hline 1.0 & 1,100 & .574 & .185 & .004 & .046 & .000 & .017 & .155 \\
\hline 1.5 & 1,300 & .552 & .200 & .000 & .071 & .000 & .004 & .163 \\
\hline \multirow[t]{2}{*}{2.0} & 1,500 & .513 & .209 & .000 & .107 & .000 & .001 & .167 \\
\hline & \multicolumn{8}{|c|}{ Gradient of stream proximity values } \\
\hline \multicolumn{9}{|c|}{ Distance from stream } \\
\hline 0 & .421 & .385 & .002 & .016 & .000 & .014 & .156 & .008 \\
\hline 100 & .561 & 178 & .017 & .034 & .003 & .073 & .146 & .029 \\
\hline 200 & .542 & .060 & .093 & .052 & .023 & .052 & .101 & .077 \\
\hline 300 & 312 & .012 & .306 & .047 & .108 & .051 & .042 & .123 \\
\hline 400 & .089 & .001 & .505 & .021 & .253 & .024 & .009 & .097 \\
\hline
\end{tabular}

a Other environmental variables held at their mean values.

${ }^{\mathrm{b}} \mathrm{NON}=$ virtually no evergreen-understory cover; $\mathrm{RHO}=$ predominantly Rhododendron maximum; $\mathrm{MIX}=$ mixed Rhododendron-Kalmia.

Model Interpretation-Predicted Probabilities

To provide ecological insights into model results, we calculated probabilities for the various change category responses, given a set of predictor variables (Tables 4 and 5). When the simple model TOPO/DIST was fitted to the Coweeta-Unmanaged data (Table 4), there was a steady increase in the probability of Rhododendron maximum persistence and expansion (RHO:RHO, NON:RHO) moving from xeric to mesic topographic settings, while the opposite was true for mixed Kalmia latifolia/Rhododendron maximum persistence and expansion (MIX:MIX, NON:MIX), as well as for persistence of unvegetated understory (NON:NON). Both loss of evergreen-understory cover (MIX/RHO:NON) and conversion from Rhododendron maximum to mixed Kalmia latifolia/Rhododendron maximum cover (RHO:MIX) exhibited progressively greater probabilities on drier topographies.

For stream proximity in Coweeta-Unmanaged (Table 4), probability of Rhododendron maximum persistence and expansion (RHO:RHO, NON:RHO) decreased with increasing distance from a stream, generally corresponding to available area in the different stream-distance classes. There was a parallel increase in the probability of persistence of mixed Kalmia latifolia/Rhododendron maximum (MIX:MIX) with increasing distance from stream. Neither mixed Kalmia latifolia/ Rhododendron maximum expansion (NON:MIX) nor evergreen-understory decline (MIX/RHO:NON) categories showed consistent patterns of variation with changing 
Table 6. Mean Values of the Environmental Variables for General UnderstoryVegetation Change Classes in Coweeta-Unmanaged and Dryman Fork Basins ${ }^{\text {a }}$

\begin{tabular}{lccccc}
\hline & Persistence & Class change & Expansion & Decline & Overall mean \\
\hline Topographic index & & & & & \\
$\quad$ Coweeta & 1.231 & 0.966 & 1.263 & 1.162 & 1.183 \\
Dryman Fork & 1.243 & 1.059 & 1.291 & 1.230 & 1.236 \\
Stream distance (m) & & & & & 96.1 \\
Coweeta & 97.8 & 66.8 & 87.8 & 93.3 & 135.1 \\
Dryman Fork & 131.8 & 174.8 & 126.4 & 153.7 & 992.4 \\
Elevation (m) & & & & & $1,067.2$ \\
Coweeta & 963.0 & 901.3 & 985.8 & 959.3 & $1,078.0$ \\
Dryman Fork & $1,064.0$ & $1,058.8$ & $1,085.3$ & & 1,8 \\
\hline
\end{tabular}

aStudent's $t$-tests indicated extremely significant differences of means $(0.0001)$ between the expansion and contraction categories in five of six cases. In the case of elevation in Dryman Fork, the differences were statistically significant $(0.01)$.

stream proximity. The likelihood of persistence of an unvegetated understory (NON:NON) increased steadily with distance from stream.

The patterns of evergreen-understory response to stream proximity were broadly similar in Dryman Fork Basin (Table 5) to those of Coweeta-Unmanaged. Both Rhododendron maximum persistence and expansion (RHO:RHO, NON:RHO) increased in probability closer to streams, whereas the probability of mixed Kalmia latifolia/Rhododendron maximum persistence (MIX:MIX) increased away from stream courses. Unlike the pattern in Coweeta-Unmanaged, both persistence of unvegetated understory conditions (NON:NON) and direct expansion of mixed Kalmia latifolia/Rhododendron maximum into previously unvegetated understory (NON:MIX) exhibited highest probabilities in intermediate stream-distance classes.

In Dryman Fork Basin, the probability of Rhododendron maximum persistence and expansion (RHO:RHO, NON:RHO) steadily increased with elevation, whereas the probability of mixed Kalmia latifolia/Rhododendron maximum persistence (MIX:MIX) steadily decreased with elevation. Elevation exerted little apparent influence on the probability of persistence of unvegetated understory conditions (NON:NON), except at the lowest elevation where the category was rare. Class conversions exhibited some sorting with elevation in Dryman Fork Basin. The probability of conversion of Rhododendron maximum to mixed Kalmia latifolia/ Rhododendron maximum cover (RHO:MIX) displayed a pronounced peak in the lowest elevation class; the opposite pattern was evident for conversion of mixed Kalmia latifolia/Rhododendron maximum to Rhododendron maximum cover (MIX:RHO).

The mean values of the environmental variables at the basin level for each of the general change categories (persistence, expansion, decline, class conversion) underscored important generalizations regarding evergreen-understory change during the study period (Table 6). Most notably, expansion of the evergreen understory 
in both basins consistently occurred on moister settings. When compared with either overall basin mean values, or with the decline category, expansion preferentially occurred in moister topographic settings (on north-facing, concave slopes and valley bottoms), at higher elevations, and closer to streams.

\section{DISCUSSION}

\section{Sources of Modeling Error}

Logistic-regression models of evergreen-understory changes in Coweeta Lab between 1976 and 1993 displayed modest predictive power. Three general sources of error contribute to the lack of predictive success of our models: problems embedded in GIS-data base development, inaccuracies in air-photo interpretation, and miss-specification of the logistic-regression model. Regarding GIS development, the quality of digital elevation models (DEM) from which aspect and elevation were derived is potentially open to question (Walsh, 1989). However, our DEM was calculated from a large-scale map (1:7200) with a 3-m contour interval, which should enhance its accuracy. The rugged terrain in the Coweeta area presents additional difficulties in making accurate photogrammetric measurements. Although vegetation polygons were stereoscopically digitized and National Map Accuracy Standards were met (U.S. Bureau of the Budget, 1941), there remains the possibility of small errors, which then propagate themselves throughout the GIS analysis in unpredictable ways.

Difficulties in the air-photo interpretation process primarily involve errors in pixel classification and differential quality of the images on which analyses were based. Ground-truth accuracy was assessed at $78 \%$ for the more recent photo mosaic (Dobbs, 1995). Vegetation mapping is complicated by fuzzy boundaries in transition areas, pixels of mixed composition, and interpretive subjectivity. These problems are well known, and cannot be avoided. A further complication is the differential visibility of the understory between photo mosaics of the two time periods. The use of large-scale photography taken during the dormant season minimizes these concerns, but cannot eliminate them as a source of error in the final models.

Misspecification ensues when important potential explanatory variables are left out of the model. In our models, historical effects of both natural and anthropogenic disturbance clearly contribute to Rhododendron maximum understory expansion, but they are not spatially quantifiable, given our sketchy understanding of that history in the study region, and so cannot be incorporated in the final models.

\section{Environmental Correlates of Evergreen-Understory Changes}

Expansion of the evergreen understory at Coweeta Hydrologic Lab is apparent between 1976 and 1993 in both direct (new establishment or extension of existing patches) and indirect (class conversion) forms. The initial premise of this study was that the Coweeta and Dryman Fork basins were physically comparable and that Coweeta-Unmanaged and Dryman Fork were broadly similar in their land-use/ disturbance histories. Indeed, between-basin comparisons reveal a number of 
general similarities. In both basins, evergreen-understory expansion is occurring at virtually identical rates (ca. $8 \%$ areal increase during the 17 -year period). In both basins, expansion is more prevalent on mesic settings while contraction, where it occurs, is more evident in drier sites. Stream proximity is important in both basins, although topographic setting is more influential in Coweeta and elevation in Dryman Fork. Areas of predominately Rhododendron maximum preferentially expand closest to streamside in both basins, on cooler, moister slopes (especially in Coweeta Basin-Unmanaged), and at higher elevations (especially in Dryman Fork Basin). The apparent contraction of mixed Rhododendron maximum/Kalmia latifolia in Dryman Fork appears to be largely the result of class conversion to Rhododendron maximum cover. Although evergreen-understory changes in Coweeta Lab show consistent associations with environmental gradients of water supply, physical conditions alone are not sufficient to explain the net expansion of the evergreen-understory or interbasin contrasts in expansion details. These require qualitative consideration of past land-use and disturbance histories.

\section{Historical Land Use and Disturbance Effects on Evergreen-Understory Change}

While environmental constraints may set the limits within which understory ericads can establish, persist, and expand, the effect of land use and disturbance history often shapes patterns of change in the landscape. For example, Dryman Fork was more recently and extensively logged, and the percentage of timber removed was uniformly higher throughout Dryman Fork Basin than Coweeta Basin. The more recent nudation in Dryman Fork Basin might account for the greater proportional area of sparsely vegetated understory in this basin. Moreover, while chestnut blight affected both basins in a dramatic way, the demise of American chestnut is slow, in general, and slower still at higher elevations (Woods and Shanks, 1959). Dryman Fork Basin has a higher mean elevation than does Coweeta Basin, and it is feasible that chestnut mortality in Dryman Fork lagged that of Coweeta Basin, thereby retarding the availability of rotting logs as a seedling substrate for Rhododendron maximum. These historical differences between basins collectively impose a higher magnitude of more recent stresses in Dryman Fork, and suggest the possibility that the evergreen understory in that basin is in an earlier state of compositional recovery from these large disturbance events.

The rapidly aggrading second growth forest that cloaks much of Coweeta Lab today has been effectively protected from fire and other areally extensive disturbance agents since the 1930s. In their stead, canopy-gap formation acts as the primary form of overstory disturbance, whether induced by localized wind events or triggered by periods of drought (Clinton et al., 1993). Rhododendron maximum exhibits considerable flexibility in regenerative response to disturbance. Sexually produced seeds can colonize open terrain rapidly, if a seed source is present. The combination of logging, cessation of repeated burning, and demise from chestnut blight in the early decades of the 20th century may well have provided a trigger for Rhododendron maximum expansion. Once established, even canopy gaps generated by individual tree-fall will reinforce the slow expansion of Rhododendron maximum by vegetative layering. Hence, the species is well positioned to expand 
its influence in response to the sequence of disturbance events and land-use changes that have characterized the past century.

\section{Possible Scenarios for Recent Evergreen-Understory Dynamics}

Based on our understanding of disturbance history at Coweeta, at least three possible scenarios could be invoked to explain current patterns of evergreenunderstory dynamics. First, the evergreen understory may simply be spreading into remaining available areas of preferred habitat, some of which likely escaped settlement or logging early in the century as a result of inaccessibility. Relaxation of the disturbance controls to Rhododendron maximum establishment-grazing, logging, and particularly fire-gave rise to a gradual occupation of physically suitable habitats. In support of this hypothesis, our results show expansion into higher elevations and into some of the steeper areas of the basins. In this scenario, the evergreen understory can be viewed as making a transition from a disturbance-controlled state to a disturbance-suppressed state in which Rhododendron maximum is gradually expanding into a range controlled by its physiological tolerance limits.

As a second scenario, what seems to be areal expansion may in fact represent a range adjustment in response to broad-scale climate changes reflected in warmer temperatures and alterations in precipitation patterns, with colonization of newly suitable habitat and contraction in newly unsuitable habitat. Our results indicate that wetter areas, such as more mesic topographies, higher elevations, and locations near streams, were the target zones for Rhododendron maximum expansion from 1976 to 1993 in both basins. Such a pattern of expansion would be consistent with progressive climatic warming in the past several decades. In the early stages of a range shift, contraction, in the form of dieback, would lag expansion and be less apparent. This interpretation is also supported by our results; contraction was seen in areas of drier topographic settings everywhere, although the magnitudes of deviation from mean values were not as great as for expansion. Under this scenario, we are witnessing a transition from one physically controlled state to another.

As a third scenario, the observed evergreen-understory changes could represent a new pulse of expansion. The conjunction of several unusual disturbance events early in the 20th century may have triggered a massive establishment of Rhododendron maximum at Coweeta Lab. Chestnut blight and serious drought likely contributed a flush of nutrients and increased light levels following canopy mortality favoring both vegetative and sexual reproduction of Rhododendron maximum, and ultimately provided a seedling substrate in the form of mossy logs. Cessation of logging and grazing and the subsequent suppression of burning enabled the persistence and gradual expansion of this understory layer. The severe drought of the early 1980s, followed by a record high precipitation year, could have provided the trigger mechanism for a renewed pulse of expansion during the study period. Under this "opportunistic expander" scenario, disturbance regime changes cause shifts from one disturbance-structured understory cover-pattern to another.

Given the qualitative nature of our understanding of disturbance effects in the study region, we cannot unequivocally embrace one of these scenarios over the others. Indeed, an attempt to favor one scenario would impose unnecessary, 
simplifying restrictions on our understanding of the understory-expansion process. Our outcome suggests a complex response involving elements of environmental adjustment both to changing physical factors (like temperature and precipitation) as well as to changing disturbance regimes and prevailing land-use practices. Although logistic modeling has provided some insights into patterns of evergreenunderstory expansion at the Coweeta Hydrologic Laboratory, it cannot capture the full range of explanatory factors and confounding interactions, both environmental and historical, that collectively influence the spatial and temporal dynamics of the evergreen understory.

Acknowledgments: We thank Wayne Swank and the staff at the Coweeta Hydrologic Laboratory for logistical support in the field, Ron Carroll, C.P. Lo, Marguerite Madden, Darrel Morrison, and Kathy Parker for advice in project development and execution, and Tom Hodler for assistance in electronic handling of the graphics.

\section{REFERENCES}

Agresti, A. (1996) An Introduction to Categorical Data Analysis. New York, NY: John Wiley \& Sons.

Akashi, Y. and Mueller-Dombois, D. (1995) A landscape perspective of the Hawaiian rain forest dieback. Journal of Vegetation Science, Vol. 6, 449-464.

Baker, W. L., Honaker, J. J., and Weisberg, P. J. (1995) Using aerial photography and GIS to map the forest-tundra ecotone in Rocky Mountain National Park, Colorado, for global change research. Photogrammetric Engineering and Remote Sensing, Vol. 61, 313-320.

Bian, L. and West, E. (1997) GIS modeling of elk calving habitat in a prairie environment. Photogrammetric Engineering and Remote Sensing, Vol. 63, 161-167.

Brzeziecki, B., Kienast, F., and Wildi, O. (1993) A simulated map of the potential natural forest vegetation of Switzerland. Journal of Vegetation Science, Vol. 4, 499-508.

Clinton, B. D., Boring, L. R., and Swank, W. T. (1993) Canopy gap characteristics and drought influences in oak forests of the Coweeta basin. Ecology, Vol. 74, 1551-1558.

de Swart, E. O. A. M., van der Valk, A. G., Koehler, K. J., and Barendregt, A. (1994) Experimental evaluation of realized niche models for predicting responses of plant species to a change in environmental conditions. Journal of Vegetation Science, Vol. 5, 541-552.

del Barrio, G., Alvera, B., Puigdefabregas, J., and Diez, C. (1997) Response of high mountain landscape to topographic variables. Landscape Ecology, Vol. 12, 95115.

Delcourt, H. R., and Delcourt, P. A. (1997) Pre-Columbian Native American use of fire on southern Appalachians landscapes. Conservation Biology, Vol. 11, 10101014.

Dobbs, M. M. (1995) Spatial and Temporal Distribution of the Evergreen Understory in the Southern Appalachians. Unpublished Master's thesis, Conservation Ecology and Sustainable Development, University of Georgia, Athens, GA. 
Dobbs, M. M. (1998) Dynamics of the Evergreen Understory at Coweeta Hydrologic Laboratory, North Carolina. Doctoral dissertation, Department of Geography, University of Georgia, Athens, GA.

Domencich, T., and McFadden, D. (1975) Urban Travel Demand: A Behavioral Analysis. Amsterdam, The Netherlands: North-Holland.

Douglass, J. E. and Hoover, M. D. (1988) History of Coweeta. In W. T. Swank and D. A. J. Crossley, eds., Forest Hydrology and Ecology at Coweeta. New York, NY: Springer-Verlag, 17-31.

Hamilton, L. C. (1992) Regression with Graphics: A Second Course in Applied Statistics. Belmont, CA: Duxbury.

Hammett, J. E. (1992) The shapes of adaptation: Historical ecology of anthropogenic landscapes in the southeastern United States. Landscape Ecology, Vol. 7, $121-135$.

Jensen, J. R., Narumalani, S., Weatherbee, O., Morris, K. S. J., and Mackey, H. E., Jr. (1992) Predictive modeling of cattail and waterlily distribution in a South Carolina reservoir using GIS. Photogrammetric Engineering and Remote Sensing, Vol. 58, No. 11, 1561-1568.

Liao, T. F. (1994) Interpreting Probability Models: Logit, Probit, and Other Ceneralized Linear Models. Thousand Oaks, CA: Sage.

Narumalani, S., Jensen, J. R., Althausen, J., Burkhalter, S., and Mackey, H. E. (1997) Aquatic macrophyte modeling using GIS and logistic multiple regression. Photogrammetric Engineering and Remote Sensing, Vol. 63, 41-49.

Nelson, T. C. (1955) Chestnut replacement in the southern highlands. Ecology, Vol. $36,352-353$.

Parker, A. J. (1982) The topographic relative moisture index: An approach to soilmoisture assessment in mountain terrain. Physical Geography, Vol. 3, 160-168.

Swift, L. W., Jr. (1988) Climatology and hydrology. In W. T. Swank and D. A. J. Crossley, eds., Forest Hydrology and Ecology at Coweeta. New York, NY: Springer-Verlag, 35-55.

U.S. Bureau of the Budget (1941) United States National Map Accuracy Standards. Washington, DC: U.S. Government Printing Office.

Walsh, S. J. (1989). User considerations in landscape characterization. In $M$. Goodchild and S. Gopal, eds., The Accuracy of Spatial Databases. London, UK: Taylor \& Francis, 290.

Whittaker, R. H. (1956) Vegetation of the Great Smoky Mountains. Ecological Monographs, Vol. 26, 1-80.

Woods, F. W. and R. E. Shanks (1959) Natural replacement of chestnut by other species in the Great Smoky Mountains National Park. Ecology, Vol. 40, No. 3, 349-361.

Wrigley, N. (1985) Categorical Data Analysis for Geographers and Environmental Scientists. New York, NY: Longman. 